\title{
Development of Teachers as One of the Priorities in the Management of the University
}

\author{
Seweryn Cichoń \\ Czestochowa University of Technology, Częstochowa, Poland
}

\begin{abstract}
Managing the development of teachers is one of the main tasks of the university, which has to be high in the rankings of universities in the era of highly competitive. The involvement of universities in this aspect is made possible by appropriate management measures. It can be seen that the same process for training core competencies to assist teachers in the implementation of the tasks is very important in the management of a specific organization. There are many duties of lecturers in the real world and in the idealism. There are many duties for teachers, such as teaching, researching, connecting with social, assessing document, and managing faculty which obstruct the career advancement.
\end{abstract}

Keywords: university management in the context of the scientific teaching, key competencies teachers, staff training process, scientific advances, the need for staff

\section{Introduction}

University management is to direct all of its resources, which consist of four capitals as follows (Stankiewicz, 2005, pp. 98-100):

(1) financial capital or various forms of money needed for the functioning of the organization;

(2) physical capital, among others buildings, including structures, land, materials, location, networks, and applied art;

(3) human capital created by the staff (scientific staff - teaching, administrative staff) and their knowledge, experience, intelligence, relationships, and law;

(4) organizational capital (which includes the processes of planning, organizing, controlling, and coordinating), organizational culture, and relations with the environment.

With these resources, the university in the article focuses on the functioning of the academic staff in higher education. Management (organization) must have the purpose of the action, that is, to see the future state of affairs or process intended by the offender, in areas, such as education, including the status of the individual or group that is to be produced or maintained in order to meet the needs of the people (Pszczołowski, 1978). Based on this definition (referring to the management of the institution of higher education), it can be concluded that the efficient operation of universities in education for employees - teachers, can contribute to meeting the needs of the latter.

Seweryn Cichoń, Ph.D., management of organization, Czestochowa University of Technology, Czestochowa, Poland.

Correspondence concerning this article should be addressed to Seweryn Cichoń, ul. Liliowa 36, Czestochowa 42-200, Poland. E-mail: sew78@interia.pl. 
Management of academic staff as one of the main resources of the university is a sequence of consecutive actions involving the efficient use of human potential, in order to ensure the best functioning while meeting the ambitions and needs of the employee (Ściborek, 2004).

The managing professional development of employees (career management) is a range of activities of the organization and employees to prepare employees for the smooth execution of tasks and occupy positions corresponding to the plans of the organization. The composition of these measures including, among others, identifying staffing needs, capabilities development and evaluation of employees, and improvement and up-skilling of staff. The management activities of staff professional development should be aimed at achieving the following objectives (Listwan, 2005): (1) to meet the future needs of the organization in terms of staffing key; (2) to ensure the smooth execution of tasks through employment and preparation in terms of qualification appropriate personnel; (3) the possibility of the organization to meet the needs of self-realization and recognition by personnel predisposition; and (4) as an incentive system, to contribute to increasing the commitment and loyalty of employees against the employer.

The realization of these objectives may also relate to the university, which scientific staff-teaching creates the prestige. A huge role in this respect by the management of the university authorities, should be consistent with the mission and vision of the organization in which one of the priorities is the development of teachers. The aim of this article is to demonstrate the impact of the university authorities on the development of teachers and lecturers and discuss the core competencies to help the implementation of scientific tasks - teaching and presenting themselves for training activities.

\section{Key Competences for Teachers to Help in the Implementation of Scientific Tasks: Teaching at the University}

University teacher is a profession that is based on teaching others, communicating specific messages, and teaching students (Okoń, 1996). This is considered as one of the largest and is variously defined. The teacher is a person having recognized personal predisposition and competence supported by appropriate tertiary education, directional, and pedagogical preparation for teaching career in education in higher education (Malinowski, 1995).

University teacher is a person who is qualified to teach the education of youth. The teacher educates, nurtures, and develops under his care students. The effect of his work also depends on the students, the program (i.e., training and education), and on the external conditions, but primarily from the teacher (Okoń, 1987). Academic teacher is adequately prepared to work by teaching specialist - education of educational institutions and non-public (universities) (Milerski \& Śliwerski, 2000). Encyclopedia teaching in 21st century as a teacher determines the learner by relaying messages (content), introducing the world of values and shaping competence and skills, including learning throughout life (Milerski \& Śliwerski, 2000). The modern university teacher is professional, prepared well, educationally, psychologically, and methodically. It is a source of knowledge, ethical values, and social experience and life in a changing world: It triggers the activity of learners and supports their development (Milerski \& Śliwerski, 2000). An academic teacher can not only be a specialist in the subject, which teaches, but also be a man, thinking creatively, empathic when dealing with others, and responsive to the needs of the student. Teacher no longer serves the function only source of knowledge, but it is to be an advisor, consultant, animator, and organizer of the process of education and upbringing. He is required to have professionalism, creativity, ingenuity to innovate, and have the ability to introduce democratic 
mechanisms to organize a class team (Grzegorzewska, 2008).

The tasks for full professor are assessed by the superior and then by the university management. Each teacher shall be subject to periodic evaluation of academic work, which includes quantitative and qualitative aspects. It gives feedback, whether the employee meets the requirements of the job (Zieleniarski, 1981). Nerwińska (2004) noted that the lecturer should primarily stimulate student, assist him in the process of self-learning and getting information from various sources, and motivate and arouse curiosity. In this approach, constructivist university teacher roles can be classified to four parts as follows (Zawadowska, 2005): (1) teacher as a guide, which is a competent subject (subject knowledge and skills, including building programs, the use of different teaching strategies, communication, and selecting and using a variety of sources); (2) teacher as a diagnostician, who is a competent to evaluate and monitor the students' progress and results of their work; (3) teacher as a manager, who is a competent to manage a group (group animation discipline and motivation); and (4) teacher as facilitator, who is the organizer of group processes.

Urbaniec (2012) argued that it is necessary to place emphasis on active learning and transfer of new experiences to students by teachers. In many education systems, Italy, Germany, Spain, and Poland represent the fundamental departure from the traditional approach. That concept should be applied by all stakeholders at the management level universities, where the partnership and exchange of good practices are the basis for changes in education (Urbaniec, 2012). For the implementation of specific academic, teacher as a professional must have the appropriate expertise.

Competences are the powers of the office or official to deal with specific issues and make decisions on them: the scope of one's knowledge, skills, and experience.

The encyclopedia of the 21 st century's pedagogical competencies is recognized as a collection of many skills, disposition, attitudes, and values necessary for the effective implementation of the assigned tasks, in other words, the ability to act motivated and adequately to the situation and knowledge (Pilch, 2004). They are divided into three basic groups of academic competence (Pilch, 2004). First competence is based on the agreement with students and colleagues, for example, the necessary level of intellectual and moral development, the required level of social development, and the ability to absorb and observe certain rules of ethical, social, and etc. Secondly, the necessary competences are those without which the person who has the teaching profession could not work constructively. To fulfill the tasks assigned to the educational institution, interpretive powers, auto-creation, and realization can be distinguished here, which are acquired in the course of vocational training.

Kocór (2011) classified academic competence because of actions: first, substantive action concerning the content of the subjects taught or blocks; second, activities of pedagogical-psychological, relating to the planning, organization and management education, upbringing and care, and the use of methods and techniques; finally, educational activities related to different ways of pedagogical proceedings to which they belong in communication skills in motivating, training students' attitudes, problem solving, cooperation, and collaboration.

Meanwhile, Marszałek and Olejniczak (2015) classified the two competences. Practical moral competence is powers of interpretation, which understands the ability to relate to the world, such as understanding as requiring continuous interpretation of reality and continual extraction of sense. In addition, moral competence is the ability of moral reflection, such as communication skills or the ability of box way of life in dialogue with the other person. The second competence is technical competence which is the ability of support (standard) or 
the ability to champion the instrumental objectives and identify with them. For instance, methodical competence is the ability to act, according to the rules that determine the optimal order of operations. In addition, power of execution is the ability to choose the means and create favorable conditions for achieving the desired objectives.

From the above classification of academic competence, they must constantly improve their skills and knowledge. University managers are interested in whether academics develop, follow the changes, and carry out tasks in different ranges. Lecturers are evaluated by the heads of organizational units in the field of research, teaching, and organization. In terms of scientific activity, the followings are evaluated: scientific advancement (for the title of professor, Ph.D. degree, doctoral degree, the position of full professor, associate professor position); publishing: peer-reviewed publications, monographs, textbooks academic citation practical applications of research, research projects, other scientific activities, and training of research staff. In the area of teaching, academics are assessed both by students and by classes hospitalized. When it comes to organizational activity, scientific staff - teaching staff is assessed in terms of his duties and on the basis of the work of the various committees, for example, recruitment and other election. Only effective teachers are developing properly the basis for developing the university and contribute to a good evaluation from the competition. University should create favorable conditions for the development of academic staff, which, inter alia, provide the means to participate in national and international conferences, enable action to be new, innovative projects, finance publication of scientific, and etc.

\section{Academic Activities in the Field of Education}

Progress in science, technology, and technical causes that teaching in higher education must be even more effective. Quality of educational services in this regard is of great importance, as it creates and builds scientific staff-teaching. A trend is noted that universities now compete with each other. Effectively educating university teacher is a showcase of the university and also creates its quality. It seems inevitable that universities should be adapted to a sharp jump in the field of communication and globalization of knowledge and broad their access to these resources. This is so important for the students that it is more often seen as one of the arguments when choosing a university. College graduates want to have the skills and knowledge at a level to be competitive in the labor markets. It depends, inter alia, just on the scientific staff-teaching (Cichon, 2013).

There are four new approaches to education and scientific staff-teaching related to the implementation of specific modules: First module includes training in teaching the course content of the field of study; the second module which is training in pedagogical consists of psychological and participation practices aiming at, inter alia, the accumulation of experience - care, knowledge acquisition skills of students with special educational needs, as well as the practical application of psychological knowledge - teaching; the third module refers to training in teaching, mastery of knowledge of general didactics and present, as well as the use of knowledge and confrontation in pedagogical practice; and the fourth module includes training content from the scope of the subject matter, content of the teaching of the subject and practice, during which the student acquires the ability to use the theory in practical operation.

The modern education teacher poses new challenges in terms of working with the student and team collaboration on the development of pedagogical college and explores their individuality and creative aspirations. Rising expectations of the teachers are the consequence of socio-economic and cultural changes 
taking place in Europe and Poland. The tasks of higher education focused on preparing the younger generation for participating in the life of a democratic society. Students have to meet the challenges of the 21 st century and should be equipped with a system of values, solid knowledge, skills, and competence. Education is the most important task of the students needed to design their own future through individual development (Cichon, 2007).

Academic education standards take into account the demands for changes in the teacher education process put forward by many researchers in recent years (Banach, 2006).

They appealed mainly to teachers in the educational process and pay more attention to the educational aspect. To awaken the teachers' proactive stance lifelong learning from various sources, there should be an emphasis on new technologies that can then be used in working with their students. University teacher's professional development is necessarily linked to its improvement, which performs many functions in this process (Kazimierowicz, 2009): firstly, the function of information sharing of technical knowledge and the latest psycho-pedagogical; secondly, compensating function complementing the knowledge and skills necessary to solve difficult problems, as well as the acquisition of new areas of knowledge and skills that ensure the effective implementation of the educational process — educational; thirdly, function to self-inspiring self critical reflection on their own work and the search for new methodological and organizational solutions; fourthly, function dissemination of best practice teaching, research results, and scientific publications; fifthly, organizational function for efficient collective and individual forms of training, applied to the identified needs of schools, teachers, and students; sixthly, compensatory function consisting of completing education to the level required by the profession; seventhly, implementation function boiling down to the acquisition news and practical skills while making a variety of educational activities; and finally, renovation function binding the constant upgrading of knowledge and skills the employee in connection with the progress of the field work. It is noted that the practical skills of teachers in the educational process also play an important role, including, among others, practical application of teaching methods, practical measures and teaching materials, the ability to effectively teach students in such a way that they were excited to think for themselves, and innovative and creative attitudes with skillful use of participatory methodologies (Dziwińska \& Cichoń, 2012).

\section{Conclusions}

College should have the resources to use the results of the personnel policy of the specific organization. In the 21 st century, there is a need for new and innovative look at grading system. The university authorities managing it effectively seek teachers capable of continuous learning, characterized by values, such as innovation, creativity, and adaptability openness to new trends in the environment, because this will translate directly to job performance. It will be noticed that it departs from the opinion of superiors for evaluation by a team of staff for the good organization of team work (Dzieńdziora, 2006). Employee assessment is paying off and the authorities and their subordinates understand the rules and the process of evaluating, which are subjected to. Thus, management-oriented universities' academic staff, their development, and continuous improvement, commitment to the tasks and responsibilities of employees, give success of the entire organization. According to the regulation of the minister of education to prepare for the academic profession, it should lead to the acquisition of competence in areas, such as teaching, education, and social and creative communication and information - the media (Muchacka \& Szymańska, 2008). Professional development of teachers is an activity of an elementary precondition empowerment. In a market, economy development of 
higher education faculty is considered to be an important element influencing their involvement in the affairs of the organization and its effective functioning. Professional development research - teaching can take place from the beginning of their work until its completion (Gajda, Cichoń, \& Gaudy, 2013).

Thus, one of the main tasks in the management of the university is to take care for a permanent and sustainable development of staff, including teachers. Institution of higher education management development-oriented academics requires the authorities to have certain ways of doing things, which are intended to work in order to meet the needs of the people within the organization and outside- for the environment.

\section{References}

Banach, C. (2006). The teacher against education reforms. In B. Muchnacka and W. Kogut (Eds.), Education of future school teachers. Kraków: Oficyna Wydawnicza IMPULS.

Cichoń, S. (2007). Methodological bases of the vocational education of teachers. Częstochowa: Wydawnictwo Politechniki Częstochowskiej.

Cichoń, S. (2013). Quality of education in the higher education institution. Częstochowa: Wydawnictwo Politechniki Częstochowskiej.

Dzieńdziora, J. (2006). The image of human resource management in administration. Katowice: Wydawnictwo AE.

Dziwińska, A., \& Cichoń S. (2012). Methodology of teaching vocational subjects-Selected issues. Częstochowa: Częstochowskie Wydawnictwo Naukowe.

Gajda, J., Cichoń, S., \& Gaudy, A. (2013). Professional development of the employee of organization as an element which determines its sense of identity. Wydawnictwo Wyższej Szkoły Bezpieczeństwa w poznaniu, 18, 137-152.

Grzegorzewska, M. K. (2008). The impact of changes resulting from educational reform on the stress levels of teachers. In B. Muchacka and M. Szymański (Eds.), The teacher in the modern world. Kraków: Oficyna Wydawnicza Impuls.

Kazimierowicz, M. (2009). Professional development of teachers. Nowa Szkoła, 53, 26-27.

Kocór, M. (2011). The competence of the future and currently active teachers. Education and Dialogue, 226, 5.

Listwan, T. (2005). Dictionary of HR management. Warszawa: Wydawnictwo C. H. Beck.

Malinowski T. (1995). The teacher and society. Warszawa: Wydawnictwo PWN.

Marszałek, M., \& Olejniczak, K. (2015). Polish teacher professional pragmatics in comparison with EU countries. Retrieved from http://www.gimkonst.pl/dokumenty/dla_nauczyciela/pz.pdf

Milerski, B., \& Śliwerski, B. (2000). Lexicon pedagogy. Warszawa: Wydawnictwo PWN.

Muchacka, B., \& Szymańska, M. (2008). The teacher in the modern world. Kraków: Oficyna Wydawnicza Impuls.

Nerwińska, E. (2004). Preparation and professional development of teachers. Caring and Educational Issues, 444, 12.

Okoń, W. (1987). Pedagogic dictionary. Warszawa: Wydawnictwo PWN.

Okoń, W. (1996). New pedagogic dictionary. Warszawa: Wydawnictwo Żak.

Pilch T. (2004). Pedagogical encyclopedia of the 21st century. Warszawa: Wydawnictwo Akademickie Żak.

Pszczołowski, T. (1978). Small encyclopedia of the phraseology and the theory of organization. Wroclaw: Wydawnictwo Ossolineum.

Ściborek, Z. (2004). People a valuable capital an organization. Torun: Wydawnictwo Marszałek.

Stankiewicz, M. J. (2005). The competitiveness of enterprises. Building competitiveness of the company in the context of globalization. Torun: Wydawnictwo TNOiK.

Urbaniec, M. (2012). Contemporary challenges of entrepreneurship education in higher education. Horizons of Education, 13, 209-230.

Zawadowska, J. (2005). Constructivism in the process of teaching/learning. The Headmaster, 27, 13.

Zieleniarski, J. (1981). Organization and management. Warszawa: Wydawnictwo PWN. 